\title{
Encountering culture on the edges - colouring and re-colouring in residential buildings: case studies of Istanbul
}

\author{
A. Kuruç \\ Department of Architecture, Architectural Design Issues Programme, \\ Mimar Sinan Fine Arts University, Turkey
}

\begin{abstract}
A residential area/house/dwelling "is a place where the human is active and penetrating most. Besides it defines an encountering space" (Uğur Tanyeli).

The act of encountering mostly happens on the edge of inner and out space relation. Colour is a changing or/and constant component in this encountering space. It tells us about not only the features of the object/building/the signified one but also the viewers, the re-users, ultimately representing the social cultural eye. Moreover, it holds the clues of social life - misunderstanding, thoughts and as-ifs in a particular culture.

In the context of this research, three residential spots are selected: from the metropolitan city of Istanbul; - a city with an elegant architecture of 1800 years - the first one is from the Historic Peninsula: Soğukçeşme Sokağ1 - a set of houses in a street from the 19th century; the second example is from the Bosphorus waterfront: Amcazade Yalıs - a waterside palace land dating back to the 17th century; and the third one is from Taksim district: Inönü Bulvarı buildings lining an avenue from the early 20th century referring to different kinds of residences and inner-outer space relations.

Selected research methodology involves analysing the case studies of Istanbul at various levels of interaction: the location of the building, the building itself and the facade.

In order to aid the analysis, the following research questions are asked:
\end{abstract}

- What causes the decisions about colour (constant/changeable) used in outer-inner spaces? 
- How this continuity of relation is maintained in terms of use of colour to pass on the memories of the place?

- Are there any differences due to the changes of user profiles?

Through the analyses of selected cases, the impact of colour in terms of functions, users and contradictions and their interaction at various levels are clarified. In conclusion, the overall perspective gained provides a better understanding of residential areas of Istanbul that evolved over time.

Keywords: colouring, memory value, encountering spaces, residential building, Istanbul, Bosphorus, Historic Peninsula, Taksim.

\section{Introduction: encountering and colouring}

Entrances - briefly the interfaces in outer-inner space relations which define both borders and accessings are the encountering places in everyday life. We encounter socio-cultural symbols in these spaces; sounds, smells, movements and images set in both personal and social memories. Thoughts about architecture emerge in the sum of these data.

Looking at a city from a bird's eye view; we can perceive the act of billions of doors' opening and closing acts. This act corresponds with encounters in many different scales. In some cases, these spaces which we can call "entrances", appear as the location of the building, the building itself or the facades apart from the "real entrance spaces". Each door opens out to a different environment; "location" is important. In different settings and/or different cultures, the outer world merges with this interface; borders moving in and out, become ambiguous. (A legal status called "fina" in the Ottoman Empire period can be an example for this situation; the word meaning: "in front of the house or around the house" which does not actually define an exact border.) This final space carries some clues/presumptions significance about the continuing private spaces of the building. The "door" gives a reference to the "entrance facade" which is not always the front facade.
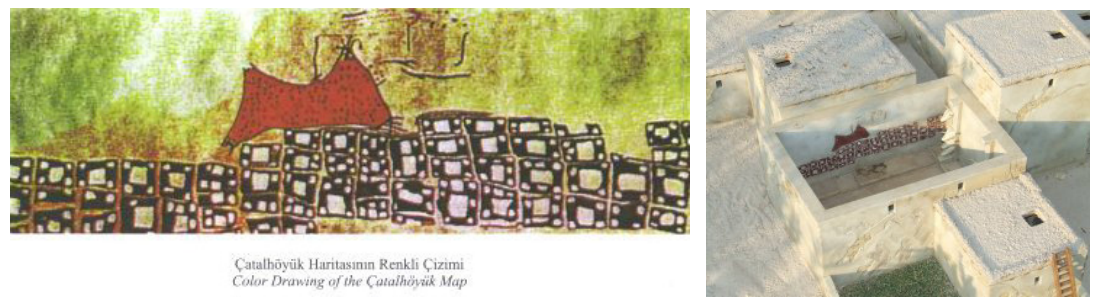

Figure 1: "Çatalhöyük is one of the first urban centres in the world (in 7400BC) The spectacular art provides a direct window into life 9000 years ago, and the site is an internationally important key for our understanding of the origins of agriculture and civilisation" [2]. The entrances of the dwellings are from their roofs, which architects often define as the fifth facade of a building today. 

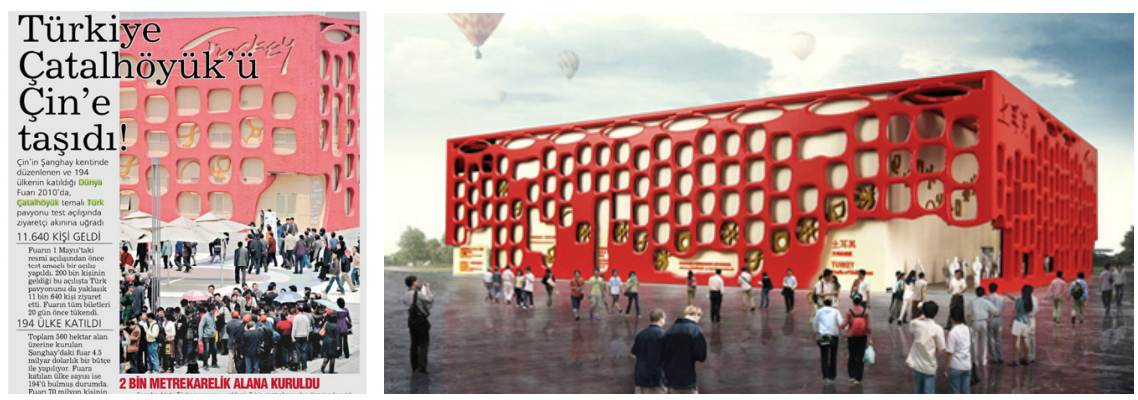

Figure 2: In 2010, the Turkish Pavilion was inspired from Çatalhöyük [3]. The plan of the settlement and the entrance holes of the housing the fifth facades - were used as a symbolic shell on the vertical facades of the pavilion. Red, a striking colour, was used (assuming two references; to the colour of dye which was used in the wall arts of Çatalhöyük and to Turkish flag colours) for this shell.

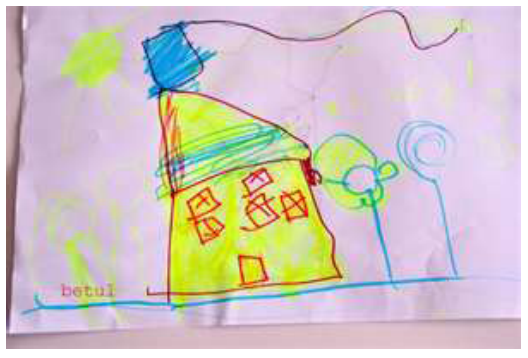

Figure 3: A child sketch of a "home".

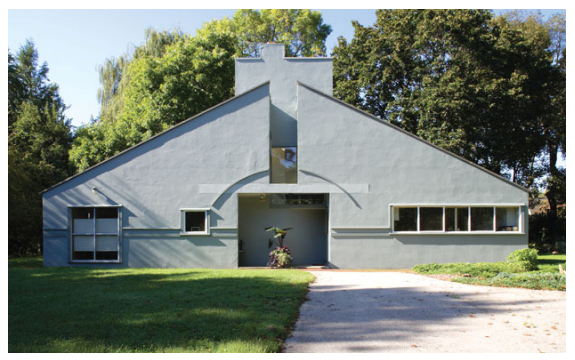

Figure 4: Venturi's “home for mother" [4].

Figures 3 and 4: "A front door serves a basic human need for symbolic meanings, isn't that also serving a function?" (Busch [5]).

However, today "door" mostly appears just in the middle of a house (see figure 3) and on the vertical surface of a building in children's sketches; which means it has a defined place in cultural and social memory way back (see figure 3).

We invoke memories through designations and images referring mostly to colour and in colour terms. This ascertainment can be based on the assumption that, in all fields of human activities and philosophy, colour was quested and used. Colour as a basic description, during the act of seeing or as perceived, appears as a part of a three dimensional space which is illuminated [5].

Today, the concept of being unsure of "seeing a certain colour just the same as others do" might correspond to the changes in evaluating colour with other dimensions, taking place in the socio-cultural environment and related matters. 
According to Branzi [6], "each nation, ethnicity or religious group creates a chromatic culture; these are subdued by industrial development, urbanism and modern communication systems". Symbolic features of colour can be both related with practical life and psychic/mental codes.

In this very bare combination, all phases of time; past, present and future occur. As Baynes [7] has stated, "the whole evaluates".

A building takes its place in the past, as soon as it is constructed. Renovations, restorations and additions become part of the building; creating memory values, giving references to different time periods. As a memory value carrier, "colour's observation may lead a way to its interpretation" (Gage [8]).

Mainly, paper aims to observe what colour as a memory value carrier, interprets in encountering spaces of three examples of different scales and time period. The concept of colour in this study, as an identifier or a path finder, is also examined as a new value/image creator.

In context, three main complexities in seeing colour as a historical object which Pastoureau defines in his book "Blue" such as, documentary, methodological and epistemological complexities might be taken into consideration, in case an ambiguity occurs in the analysing process of these examples. Basic determinations on location, the building itself and the facade features are the first steps to finding out in what scale and how colour might be an important dimension in different residential examples of the past.

\section{Colouring and recolouring in residential buildings: case studies of Istanbul}

Istanbul named as "Dersaadet", was divided into four parts in terms of judicial and administrative structure until the mid-19th century. The first part was called "suriçi/inner citywall" regarded as the centre of the town at the time. The other three parts, named "Bilad-1 Selase", involving Galata, Üsküdar and Eyüp are the counties of the current metropolitan city. These disparities in town connoted not only judicial and administrative structures but sociological and cultural structures also, which created four different spheres in a harmonious whole; the city of Istanbul [9].

In the context of encountering and colouring reading set out above, the following cases were selected from Istanbul to comparatively assess the relevant reading over time with reference to their unique location, building, facade and entrance:

- The first example is selected from inner city walls; Suriçi Soğukçeşme Street, where buildings are leaned on the Palace Walls (borders); reflecting an encountering space between the Palace and the city.

- The second example, Gümüşsuyu, İnönü Boulevard Housing located nearly at the end of the ex-Venetian city borders where this area at the same time became one of the most prestigious districts in early years of Turkish Republic; creates a historical encountering. 
- The third example, Amcazade Yalisi, as a location, is on an encountering space between the sea (Bosphorus) and the land. Ortayli [10] determines Boshorus (which itself is an encountering space) as an Ottoman civilization exposition, becoming a part of the "city" since the 18 th century.

\subsection{Case study 1: Soğukçeşme houses/ Soğukçeşme evleri (street scale)}

The street was built, as far as we know from the archives, at the end of the 18th, early 19th century, two-three storey high buildings for the upper-middle class.

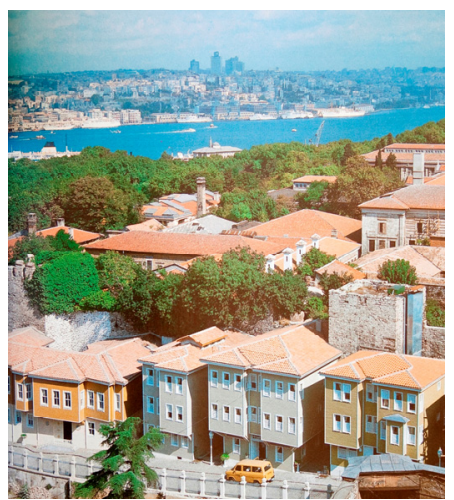

(a)

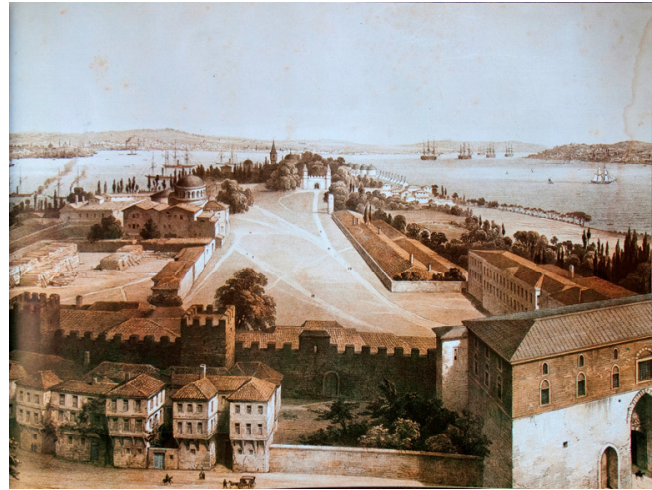

(b)

Figure 5: Soğukçeşme sokağı: (a) a view after reconstruction and (b) Fossati's gravure dating back to mid 19th century [11].

Location: This one-sided street is situated between the city palace walls (power of Sultan) and Saint Sofia Mosque's southeast garden walls (power of the past) creating a narrow distance between the two. These walls, highlighting the buildings on this narrow and short street, coincidentally display also the importance of their colouring.

Building: A traditional Turkish/Ottoman timber housing system was used in these row houses. It is not easy to make a clear confirmation about the colours of the buildings whether traditional colours were used at the beginning. However, we can make an assumption counting on Fossatti's gravure (see figure 5(b)) that the influences of European styles were in use - pale toned colours such as greyish white, white, pale green. In the gravure we can see only the tones of white for the Soğukçeşme street buildings. Actually these colours might be the reflection of the architect's own cultural approaches reflected on the gravure.

Facade: The facades create a whole image of one character; having the same materials and mostly whitish/pale colours. The Palace's wall creates a neutral background for the facades. The stress of the inner-outer relationship is on these one-sided street facades.

Entrance: The main doors are opening either directly to the entrances of the houses or to a small open-air court from the street. The doors were painted in different colours and bright tones unlike the facades as we see in the gravure. 
Blue-green colours mostly used, meaning humans can enter, whereas insects cannot. Sometimes a haci can colour his door green. It strongly defines an entrance. The doors are the primal encountering units in this example and are important.

These buildings were torn down and rebuilt as concrete constructions in the mid 1980s. The construction system has changed, the function has changed and the colours have changed. Due to the colour change, a new way of interaction with the site has occurred - the facades became the encountering spaces; not the doors or the courts that lead you to the inner space. Today, we see individual houses painted in different colours rather than a series of houses (see figure 5(a)).

Daily colour trends of the 1980s were followed up for these buildings in the reconstruction and renovation process; they were named after flowers; different tones of colours were chosen. The colours chosen were romantically made up; these buildings have become some kind of "touristic objects offering fictive originality" (Çelik [12]). Inner space colours lost their importance then. Monochrome colours were used as codes for the rooms of the boutique hotels. However, in Abdülaziz Bey's [13] book dated circa 1910, named Ottoman Customs, Ceremonies and Expressions, detailed descriptions of traditional decorations of a 19th century middle-upper class family residence, include references to the colours of every single interior item.

\subsection{Case study 2: Inönü Avenue residentials/Inönü Caddesi apartmanları series of avenue buildings)}

Mainly the buildings refer to the early and mid 20th century as upper-class residential - most of them having half-basement spaces for commerce.

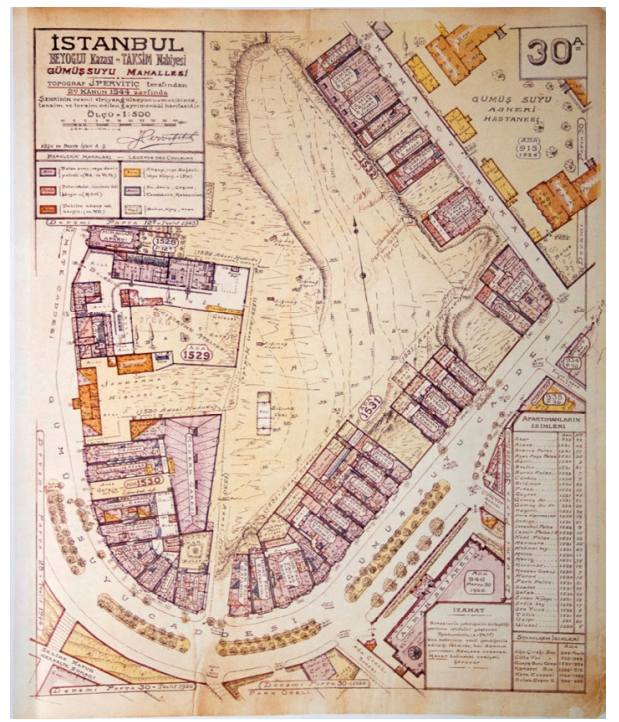

Figure 6: Inonu Avenue plan, from Pervititch map [14]. 

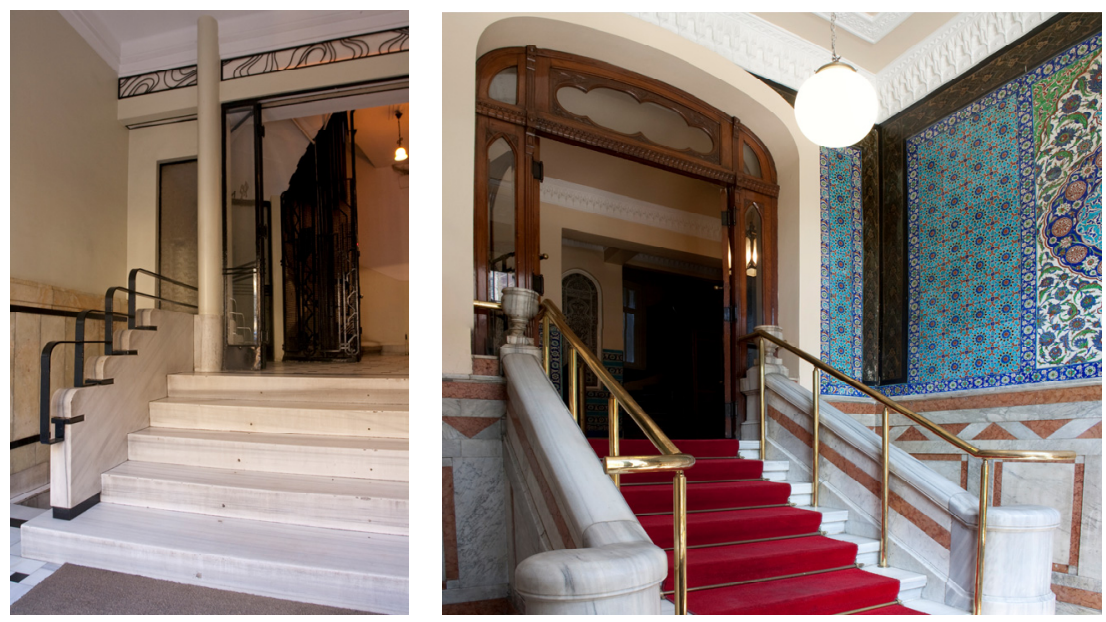

Figure 7: Entrance halls of Bosfor and Hayırlı residentials, photos: Tuba Kilıç 2010.

Location: The Avenue is on an important axis called Gümüşsuyu - getting down from Taxim Square to Dolmabahçe Palace; from a westernised centre to a symbolically westernised palace. As it is curved, you can not perceive all of the buildings in a shot. So, the facades seem to lead one to another while moving on this curvy axis.

Building: A homogeneity in visual impact grounds on some facts considering these buildings; they are all six or seven storey high concrete constructions and they have direct entrances to the avenue. They all give the impression as "designed" residential. Each one is in a different colour but they mostly have the same tones and brightness.

Facade: Differences in details on the facades stand out among the buildings. The facades have an architectural approach which continues in the entrance halls. Three years ago, the municipality repainted the facades as part of an urban facade rehabilitation project. In this re-colouring project, the buildings had again pale tones with one exception. The facades belong to a public sphere where not the users but the municipality authorities have decided the new colours.

Entrance: The "designed" entrance halls of the buildings still carry the original colours. Mostly because of the materials used - marbles, ceramics and plasters, these encountering spaces become memory collectors of the buildings. Another important supportive element of these encountering spaces are the original doors of the buildings; semi-transparent and transparent doors letting the daylight and a controlled visual approach in, giving a clue about the life of inner spaces to the outsiders and the outside life to the residents. Encountering happens in the "entrance halls" that encloses these doors reverting to both sides.

Today, some of these buildings are owned and used by firms where their facade colours continue in the deformed-changed-newly designed entrance halls. 
This new approach creates a direct contradiction concerning the value of a memory collector - colour - in these encountering spaces.

\subsection{Case study 3: Amcazade Waterside Palace/“Amcazade Yalısı” (building scale)}

The building is part of a late 17th century high-class summer residential complex.

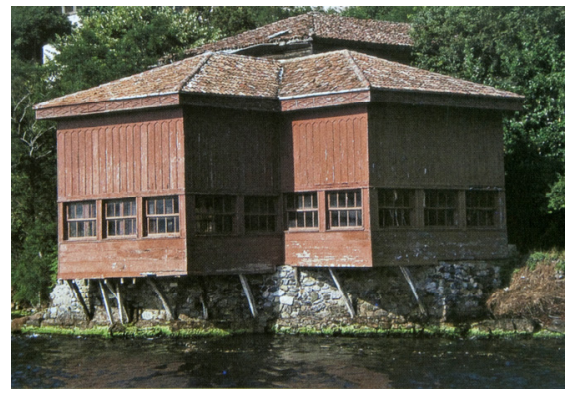

(a)

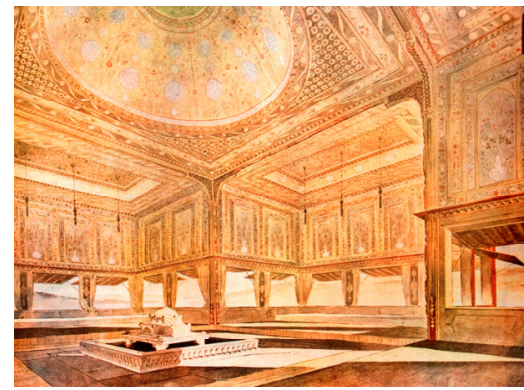

(b)

Figure 8: (a) View of Amcazade Palace from Bosphorus and (b) its inner space illustration - sketched by Sedad Hakkı Eldem, a well-known architect, analysing the complex and the palace in the mid 20th century [15].

Location: As the waterside building "yalı" is on the edge of Bosphorus, it creates an encountering space by projecting a fortuitous reddish colour reflection on the water, doubling the effect of colouring. The building governs the sight, the daily sea-traffic and shows itself as a host because of its location.

Building: The building is named Selamllk; the word selamlık refers to the function of encounter where meetings and entertaining occur; the actual interaction place of the complex.

Facade: It has an extraordinary arrangement of boarding, compared to latter yalı examples. It is a reddish box (ruddle was used to colour it) which looks like a complementary figure with green woods in the background. Residences were coloured in red when the religious belief of the family is Islam.

Entrance: The main entrance door of this building is not from the seaside. It is from an inner court - like outer space on the other side, supported by other units of the complex which do not exist today.

Through colour, a reference of culture is gained; a closed plain reddish box on the sight of Bosphorus keeping a sunny and relaxing yellowish atmosphere inside. It strengthens the feeling of differences of outer and inner life; keeping detailed inward life codes of the past. Indirect light reflects inside Selamlık, creating a controlled light in the whole space. The inner part does not have a reddish atmosphere; homogeneous colour from "a detailed mother of pearl/nacre inlayed" (Kuban [16]), yellowish ornamented wooden surfaces which surround 
and continue on the main door of the space as well. Space was set considering a sitting person's view where one can see the horizon and outer view colours. The building is not in use today. All of the buildings in the complex will be reconstructed and renovated for a hotel project. The restoration/reconstruction of Selamlık unit is still on.

Table 1: $\quad$ Effects of colour changes in encountering spaces [17].

\begin{tabular}{|c|c|c|c|}
\hline \multicolumn{4}{|c|}{ How colour changes have affected encountering spaces in three case studies. } \\
\hline $\begin{array}{l}\text { Case studies } \\
\text { Assessments }\end{array}$ & $\begin{array}{l}\text { 1. Soğukçeşme } \\
\text { Street }\end{array}$ & $\begin{array}{l}\text { 2. Gümüşsuyu } \\
\text { Boulevard }\end{array}$ & $\begin{array}{l}\text { 3. Amcazade } \\
\text { Waterside Palace }\end{array}$ \\
\hline Location & $\begin{array}{l}\text { Colours have } \\
\text { changed: Object- } \\
\text { ground relationship } \\
\text { has changed. }\end{array}$ & $\begin{array}{l}\text { Colours have not changed. } \\
\text { Not a clear difference can be } \\
\text { perceived. }\end{array}$ & $\begin{array}{l}\text { Colours presumably will } \\
\text { not change. No difference } \\
\text { in perception before the } \\
\text { reconstruction. }\end{array}$ \\
\hline Building & $\begin{array}{l}\text { Colours have } \\
\text { changed: It was } \\
\text { perceived as a series } \\
\text { of buildings where } \\
\text { today it is perceived } \\
\text { as individual } \\
\text { buildings. }\end{array}$ & $\begin{array}{l}\text { Colours have changed: On } \\
\text { the other hand the series of } \\
\text { buildings' effect is the same } \\
\text { as the same tones and } \\
\text { shades of colours are used. }\end{array}$ & $\begin{array}{l}\text { Colours presumably will } \\
\text { not change but } \\
\text { reconstructions of other } \\
\text { units/buildings on site } \\
\text { might create a different } \\
\text { balance considering } \\
\text { colour. }\end{array}$ \\
\hline Facade & $\begin{array}{l}\text { Colours have } \\
\text { changed: The doors } \\
\text { used to be the only } \\
\text { bright coloured } \\
\text { elements whereas } \\
\text { today the facades of } \\
\text { each building has a } \\
\text { bright colour which } \\
\text { doors do not have. }\end{array}$ & $\begin{array}{l}\text { Colours have not changed: } \\
\text { However, unlike entrances, } \\
\text { the colours of } \\
\text { details/ornaments on } \\
\text { facades are carelessly } \\
\text { chosen/applied and they } \\
\text { need a revision. }\end{array}$ & $\begin{array}{l}\text { Colours presumably will } \\
\text { not change. } \\
\text { Reconstruction and } \\
\text { restoration is on site. }\end{array}$ \\
\hline Entrance & $\begin{array}{l}\text { Colours have } \\
\text { changed: The } \\
\text { function has changed. } \\
\text { Inner space } \\
\text { organisations and } \\
\text { their colourings are } \\
\text { not referring the } \\
\text { original ones. }\end{array}$ & $\begin{array}{l}\text { Colours have not changed: } \\
\text { As colour in most entrances } \\
\text { either belongs to the } \\
\text { materials' colour or } \\
\text { expresses a style. Some } \\
\text { buildings are exceptional } \\
\text { examples of how the effect } \\
\text { of the entrance changes due } \\
\text { to colour. }\end{array}$ & $\begin{array}{l}\text { Colours are assumed not } \\
\text { to be changed in } \\
\text { restoration/reconstruction } \\
\text { as the inner yellowish } \\
\text { coloured ornaments create } \\
\text { a complementary effect } \\
\text { with the outside red in } \\
\text { terms of light. }\end{array}$ \\
\hline
\end{tabular}

The shaded boxes are the spaces where encountering happens predominantly. (Due to colour changes, the predominance in these assessments has changed in time.)

\section{Conclusion: evaluating selected case study findings and pointing to further research}

We had different residential examples from different time periods in Istanbul. They have unique locations, different interaction levels which can be deciphered due to the "place" itself. In these examples, the encountering process appeared in 
different scales. Based on the three examples, a kind of two layered comparative reading was considered (see scheme 1):

In the first layer, the aim was to determine where encountering happens most, by selecting and using four assessments in case studies. The second layer was to find out if the features of these encountering spaces sustaining characteristics of both being public and private, are pronounced in terms of colour.

Pre-colour/original colour decision (the previous colour might not be the real original colour) is important information for seeking the traces of "cultural and social memories" (Busch [18]), in differentiating private and public spaces, defines "the door", be a place of gracious convergence between public and private lives" which does not belong only to the people who live there. Colour is a supportive or a provocative element in this differentiation in encountering spaces. Similarly, it can be stated that, choices of original colours in these case studies can be questioned as important parts of a socio-cultural whole where central authority and public power are also involved.

Finally, it is observed that, the interventions/changes considering original colour choices refer some other states/perceptions other than the originals' in terms of spatial formations. The concept of colour as a memory collector lightens certain relations in different scales of space and has become an important part of the space itself. Re-colouring is another information root in such buildings; may be a leading element to carry on the interaction or an easy way to cut it. The information of a building may vanish in individual and collective spirit which refers to an important value: memory value of the building.

Dwellings/residentials are continual examples of civil architecture; however they easily disappear by time just like colours which pass on the socio-cultural perceptions of all times. The reality of daily life is hidden in these momentary but at the same time profound matters.

\section{References}

[1] Uğur Tanyeli is a Turkish architect and a well known architectural historian.

[2] Çatalhöyük Excavations http://www.catalhoyuk.com.

[3] Shangai Expo $2010 \mathrm{http} / / / \mathrm{www} \cdot$ turkishpavilion2010.com/tr/

[4] PRIVATE http://www.weareprivate.net/blog/?p=21123

[5] Busch, A., Geography of Home, Princeton Architectural Press: New York, NY, pp.33,1999 MacEvoy, B.2004, http://www.handprint.com/

[6] Branzi, A., Complete Works, Thames and Hudson: London, 1992

[7] Baynes K., Toplumda Sanat, (Y. Atılgan),Yapı Kredi Yayınları: Istanbul, pp.39, 2004

[8] Gage, J, Colour and Meaning, Thames and Hudson: London, pp.67. 1999

[9] Istanbul Life, http://www.istanbullife.org/dersaadet_ve_uc_istanbul.htm

[10] www.milliyet.com.tr/Pazar/HaberDetay.aspx?aType...pazar. (from an interview with İlber Ortayli)

[11] Gülersoy, Ç., Soğukçeşme sokağı, Turing yayınları: Istanbul, 2003 
[12] Çelik, Z., Favro, D., Ingersoll, R., Şehirler ve Sokaklar, İnsan ve Toplum: İstanbul, 2007

[13] Abdülaziz Bey, [Arısan, K., \& Arısan Günay, D., (eds)] Osmanlı Adet ve Tabirleri, Tarih Vakfi Yurt Yayınları: Istanbul, 2000

[14] Istanbul in the Insurance Maps of Jacques Pervitich 1925-1945, Tarih vakfi yayınlari: Istanbul, 2001

[15] Wooden İstanbul, Examples from Housing Architecture, Istanbul Araştırmaları Enstitüsü yayınları: Istanbul, pp.208,211, 2008

[16] Kuban, Z., Wooden İstanbul, Examples from Housing Architecture, Istanbul Araştırmaları Enstitüsü yayınları: Istanbul, pp.213,2008

[17] Kuruç, A. (Table composed for the case studies)

[18] Busch, A., Geography of Home, Princeton Architectural Press: New York, NY, pp.36,1999 